\title{
Effect of Multi-enzyme (Pectinase, Cellulase and Hemicellulase) Treatment on Clarification of Papaya (Carica papaya) Fruit Juice
}

\author{
Ravi Kumar, Alak Kumar Singh
}

\begin{abstract}
Clarified fruit juices are preferred by a significant portion of the population and are becoming popular in global fruit juice market. Many of the other processed fruit products like, clear juice cocktails, cordials, ready to serve drinks, clear nectars, clear juice blends, translucent jelly products, candies etc. are made from clarified juices. Apart from the traditional clear juices from apple and other citrus fruits, several market opportunities exist for clarified juices produced from the tropical fruits of high pulp content like banana, papaya, guava, mango etc. which are being produced abundantly in India. This study was carried out with an objective of producing high quality clarified papaya juice with high yield by multi-enzyme treatment. Papaya juice was given treatments with various concentration levels of the enzymes pectinase, cellulase and hemicellulase for different incubation times (30-150 min) at incubation temperature of $55^{\circ} \mathrm{C}$. The effect of enzyme treatments was studied on turbidity and yield of clarified papaya juice obtained for each enzyme separately, and optimum process conditions were determined. Based on these results papaya juice was given simultaneous treatment of all the three enzymes with compromised process conditions (Pectinase $0.90 \%$, Cellulase $0.40 \%$, and Hemicellulase $0.50 \%$ with $90 \mathrm{~min}$ incubation time at $55^{\circ} \mathrm{C}$ ) which produced clarified juice with very small value of turbidity as 11 NTU and yield as $77.4 \%$. RSM(Response Surface Methodology) employing a second order central composite design was used to obtain optimum process conditions for simultaneous treatment with the range of variables for enzymatic treatment process conditions (Enzyme concentration: $0.20-1.20 \% \mathrm{w} / \mathrm{w}, 0.20-0.80 \% \mathrm{w} / \mathrm{w}$ and $0.20-0.80 \%$ $w / w$ for pectinase, cellulase and hemicellulase respectively, Incubation time 30-150 min and Incubation temperature $55^{\circ} \mathrm{C}$ ) based on the above experiments. The results obtained for optimum process conditions were very close to that obtained in previous experiments giving the optimum values as $0.87 \%, 0.50 \%$ and $0.50 \%$ enzyme concentration for Pectinase, Cellulase and Hemicellulase respectively, and incubation period of 86 min at incubation temperature of $55^{\circ} \mathrm{C}$. Under this condition, the papaya juice was obtained with turbidity value as 9 NTU and 78.8 per cent of yield.
\end{abstract}

Keywords: Papaya Juice, Clarified Juice, Pectinase, Cellulase, Hemicellulase, Response Surface Methodology

\section{INTRODUCTION}

Papaya is a tropical fruit and is commonly known for its nutritive, medicinal as well as economic value. It is good

Revised Manuscript Received on November 15, 2019

Ravi Kumar*, Department of Food Technology, School of Chemical Technology, Harcourt Butler Technical University, Kanpur, Uttar Pradesh, India.

Alak Kumar Singh, Department of Food Technology, School of Chemical Technology, Harcourt Butler Technical University, Kanpur, Uttar Pradesh, India. source of antioxidant nutrients (e.g., carotenes, vitamin C, and flavonoids), the B vitamins (e.g., folate and pantothenic acid), minerals (e.g., potassium and magnesium), and fiber [1]. It has long been cultivated in the home gardens of people. It is the crop that bears fruit throughout the year. India ranks first in production of papaya (44.03\%) [2]. Papaya_is gaining popularity worldwide, but only $0.08 \%$ of domestic production is exported and the rest is consumed within the country [3]. In India, the post-harvest losses of papaya are estimated at 5-30 percent of total production. The mechanical injured and over ripen papaya fruits are wasted in large quantities due to absence of facilities, improper handling, distribution, marketing and lack of storage facilities. These losses can be minimized by processing of papaya fruit that also gives better return to farmer during the glut season. Under ambient tropical conditions, freshly harvested, ripe papaya fruit typically exhibit a storage potential of less than one week [4].

Generally, fruit juices are extracted by crushing and grinding and because of presence of pulp particles and colloidal suspensions, the juices obtained by these operations are viscous, turbid and cloudy. Yield of this kind of juices is low. It is also very difficult to concentrate and pasteurize them. In case of papaya also crushing and grinding do not yield juice from papaya as papayas are too pulpy and pectinaceous. Due to its high pectin content, a sticky and lumpy mass is obtained rather than juice after these operations. Papaya juice is one of the desirable papaya products, but it is virtually absent in some markets due to its high pectin content (about 10\% dry weight) [5]. So there is ample scope for production of high-value clarified juices from papaya to minimize the wastage and to earn higher foreign revenue by increasing the export of such valuable products. For the preparation of ready to serve drinks, cordials, jelly, nutritional carbonated beverages, nectars, concentrates, etc. clarified juices are in high demand [6]. A variety of products are based on clarified juices such as sparkling clear beverages (soft drinks, clear juice cocktails, cold teas with clear juice, alcoholic beverages), translucent jelly products, candies, fruit honey or fruit sugar, clear juice blends, $100 \%$ canned fruit (with clear juice as syrup) etc. Therefore, several market opportunities exist, not only for the traditional clear juice from apple, but also for clarified fruit juices produced from fruits having high pulp content [7].As a result of increasing health awareness among people, the demand for fruit juices is increasing day by day. The fruit-based juice market is growing at a compound annual growth rate (CAGR) of 25-30 per cent in the past decade. In India, the juice market is estimated to be

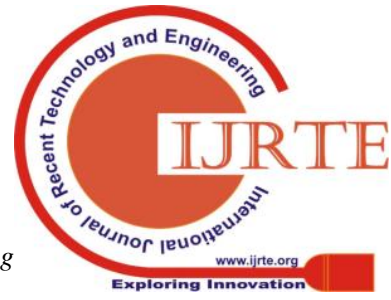




\section{Effect of Multi-enzyme (Pectinase, Cellulase and Hemicellulase) Treatment on Clarification of Papaya (Carica papaya) Fruit Juice}

around Rs. 10,781.62 crore (16 per cent of the total soft drink market in India). The fruit juice market in India is projected to grow at a CAGR of 22 per cent over the next five years, and is expected to grow more than double in the next few years [8].

In a freshly extracted juice, the semi stable emulsion of colloidal plant carbohydrates supports the insoluble cloud material. The process of clarification breaks this emulsion. During enzymatic treatment, there is reduction in viscosity because of degradation of pectin. This eases separation through centrifugation or filtration and gives the juice higher clarity. Pectinases, cellulases and hemicellulases (collectively called macerating enzymes) are used for extraction and clarification of fruit juices currently. Pectinases hydrolyze $\alpha$-1,4-glycosidic linkages of pectin molecules and produce polygalacturonic acid monomers [9]. Cellulases cleaves $\beta-1$, 4-D-glucan linkages of cellulose and produces oligosaccharides, cellobiose and glucose [10,11] while hemicellulases, a diverse group of enzymes, hydrolyze hemicelluloses, one of the most abundant group of polysaccharide found in nature [12]. The pectinolytic and cellulolytic enzymes, in combination, enhances the yield and clarity in the process of juice clarification because of simultaneous degradation of polysaccharides [13]. The effect of hydrolytic enzymes on clarification and extraction of various fruit juices have been reported in papaya $[5,14,15]$, banana $[16,17,18,19,20,21,22,23,24]$, guava $[25,26,27,28]$, litchi [29,30], mango [31,32], kiwifruit [33,34], apple $[35,36]$, pineapple [37,38], asparagus [39], peach [40], pear [41], carrot [42,43] and plums [44].

\section{MATERIALS AND METHODS}

Fruits: Fresh and mature papayas (Carica papaya) were purchased from the local market and used immediately or stored at $4^{0} \mathrm{C}$ for not more than 2 days before being used.

Enzyme Source: Commercial enzymes, BL-Pectinase, BL-Cellulase and BL-Hemicellulase (obtained from Biolaxi Corporation, Bhiwandi, India) were used for enzymatic treatment of fruit juice. BL-Pectinase was a food grade enzyme preparation specially designed for degradation of cell wall and extraction of pectic substance. The activity of BL-Pectinase was $1200 \mathrm{PGU} / \mathrm{g}$. The recommended optimum enzyme reaction conditions were $\mathrm{pH} 3.5$ to 6.0 (Optimum 3.8) and temperature $40{ }^{0} \mathrm{C}$ to $60{ }^{0} \mathrm{C}$ (Optimum $55{ }^{0} \mathrm{C}$ ). BL-Cellulase and BL-Hemicellulase were also food grade enzyme preparations designed for cell wall degradation and extraction, with the enzyme activities of 1,00,000 CMCU/g and 1,00,000 $\mathrm{HCU} / \mathrm{g}$ respectively. The optimum enzyme reaction conditions recommended, for BL-Cellulase were $\mathrm{pH}$ 4.5 to 6.0 (Optimum 4.8 ) and temperature $40{ }^{\circ} \mathrm{C}$ to $60{ }^{0} \mathrm{C}$ (Optimum $55{ }^{\circ} \mathrm{C}$ ) and for BL-Hemicellulase were $\mathrm{pH} 4.5$ to 6.5 (Optimum 4.5) and temperature $40{ }^{0} \mathrm{C}$ to $60{ }^{\circ} \mathrm{C}$ (Optimum $\left.50{ }^{\circ} \mathrm{C}\right)$

Juice Preparation: Mature papayas were washed, peeled, cut into halves and seeds were removed. Then it was cut into small pieces. A ratio of 1:1 (Papaya: water; w/w) was used in mixing process using mixer blender and a homogeneous mixture was obtained. The juice obtained was subjected to different enzyme treatment conditions. The $\mathrm{pH}$ of the juice obtained was 4.3. Figure 1 shows the steps involved in extraction and clarification of papaya juice by enzyme treatment.
Enzymatic Treatment and Optimization: The papaya juice was treated with each enzyme separately and optimum conditions for enzyme dose and incubation time were determined. For optimization of enzyme dose, the juice was treated with different doses, keeping the incubation temperature and time fixed in each experiment. For optimization of incubation time, the juice was treated for different time periods keeping the enzyme dose and temperature of incubation fixed in each experiment. Based on the optimum temperature recommendations for commercial enzymes, the reaction is carried out at incubation temperature of $55{ }^{\circ} \mathrm{C}$. The papaya juice without addition of enzyme was taken as control for enzyme dose experiments and the juice without addition of enzyme and retention time of zero min was taken as control for incubation time experiment. At the end of the enzyme-treatment, the enzyme in the sample was inactivated by heating the suspension at $90{ }^{\circ} \mathrm{C}$ for $5 \mathrm{~min}$ in a water bath and immediately cooled to room temperature. The enzyme-treated juices were centrifuged at 1100 RPM for 20 min and the supernatant was collected. The effect of simultaneous incorporation of all the three enzymes on the juice was also studied at the adjusted optimum reaction conditions obtained from the above experiments.

A four variable (five level of each) second order central composite rotatable design (CCRD) was employed to obtain optimum process conditions for simultaneous treatment of all the three enzymes by Response Surface Methodology (RSM). The independent variables were: concentration of pectinase (x1), concentration of cellulase (x2), concentration of hemicellulase (x3) and incubation time (x4). The ranges of variables selected (based on the above mentioned experiments with the individual enzymes) were as follows:

1. Enzyme Concentration (Pectinase), X1: $0.20-1.20 \% \mathrm{w} / \mathrm{w}$

2. Enzyme Concentration (Cellulase), X2: $0.20-0.80 \% \mathrm{w} / \mathrm{w}$

3. Enzyme Concentration (hemicellulase), X3: 0.20-0.80\% $\mathrm{w} / \mathrm{w}$

4. Incubation Time, X4: 30-150 min

The experimental design is shown in Table- 1 in coded $(\mathrm{x})$ and actual (X) levels of variables.

The response functions (y) were the juice turbidity and yield. The values were related to the coded variables $\left(x_{i}, i=1\right.$, 2,3 ) by a second-degree polynomial using the equation given below (Eq. 1):

$$
\begin{aligned}
& Y_{k}=b_{0}+b_{1} x_{1}+b_{2} x_{2}+b_{3} x_{3}+b_{4} x_{4}+b_{11} x_{1} x_{1}+b_{22} x_{2} x_{2}+b_{33} x_{3} \\
& x_{3}+b_{44} x_{4} x_{4}+b_{12} x_{1} x_{2}+b_{13} x_{1} x_{3}+b_{14} x_{1} x_{4}+b_{23} x_{2} x_{3}+b_{24} x_{2} x_{4}+ \\
& b_{34} x_{3} x_{4}+\varepsilon
\end{aligned}
$$

The coefficients of polynomial were represented by constant term $b_{0}$; linear effects $b_{1}, b_{2}, b_{3}$ and $b_{4}$; quadratic effects $b_{11}, b_{22}, b_{33}$ and $b_{44}$; interaction effects $b_{12}, b_{13}, b_{14}, b_{23}$, $b_{24}$ and $b_{34}$ and random error $\varepsilon$. The Analysis of Variance tables were generated and the effect of individual linear, quadratic and interaction terms were determined. The significance of all the terms in the polynomial was judged statistically by computing the probability (p) at level of 0.001 , 0.01 and 0.05 [25, 28]. For data analysis, Minitab 17.1.0 (Minitab Inc.) statistical software (trial version) was used.

Turbidity Determination: Turbidity of the papaya juice was determined using Insif India Digital Turbidity Meter (Labpro International, Ambala, 
Haryana). The results were reported as NTU (Nephelometric Turbidity Units).

Percentage Yield Determination: Percent yield was estimated as percentage of the clarified juice obtained based on the initial papaya pulp.

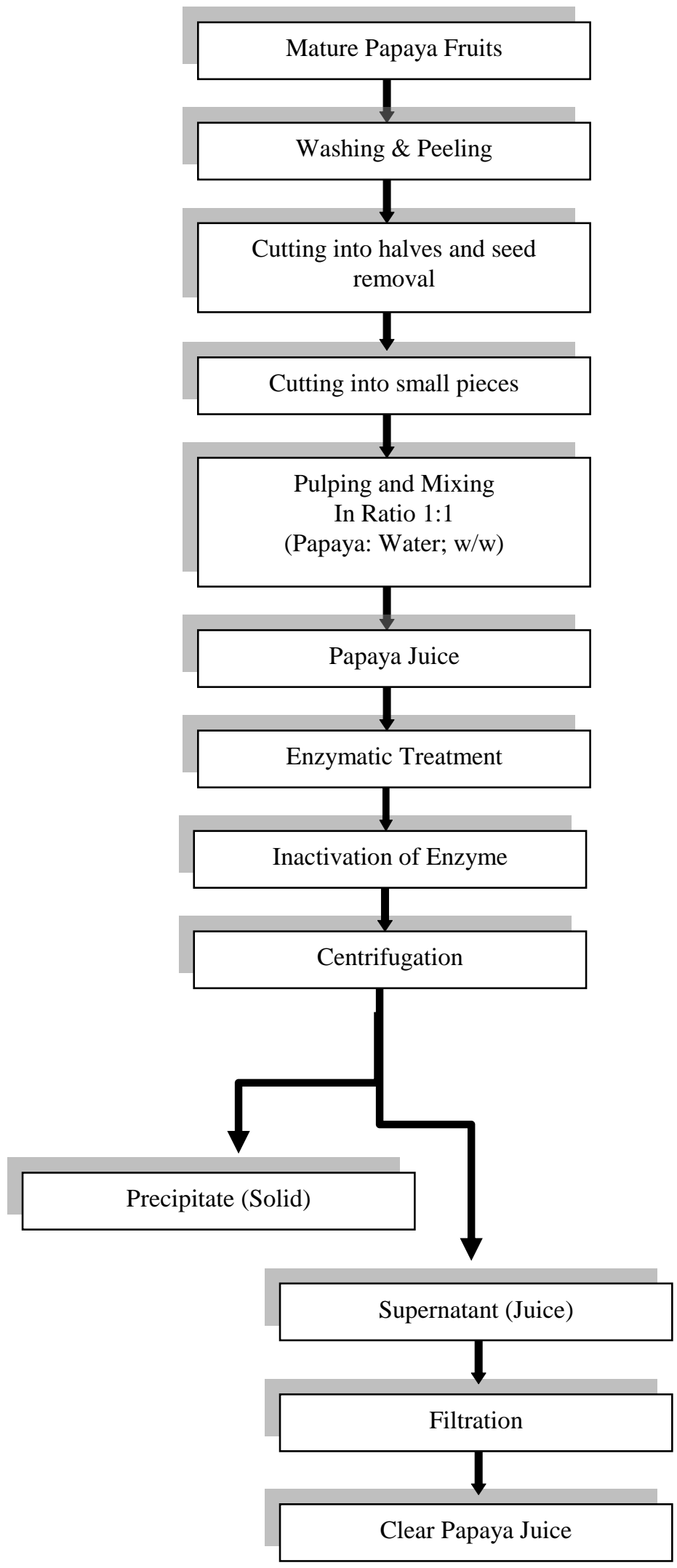

Fig 1: Steps for Papaya Juice Extraction and Subsequent Clarification by Treatment with Enzymes 
Table-1: The Central Composite Rotatable Experimental Design (in coded and actual level of four variables) employed for treatment of Papaya juice with enzymes

\begin{tabular}{lrll}
\hline \multicolumn{4}{l}{ Central Composite Design } \\
\hline Factors: & 4 & Replicates: & 1 \\
Base runs: & 31 & Total runs: & 31 \\
Base blocks: & 1 & Total blocks: & 1 \\
& & \\
Two-level factorial: Full factorial \\
Cube points: & 16 \\
Center points in cube: & 7 \\
Axial points: & 8 \\
Center points in axial: & 0
\end{tabular}

$\alpha: 2$

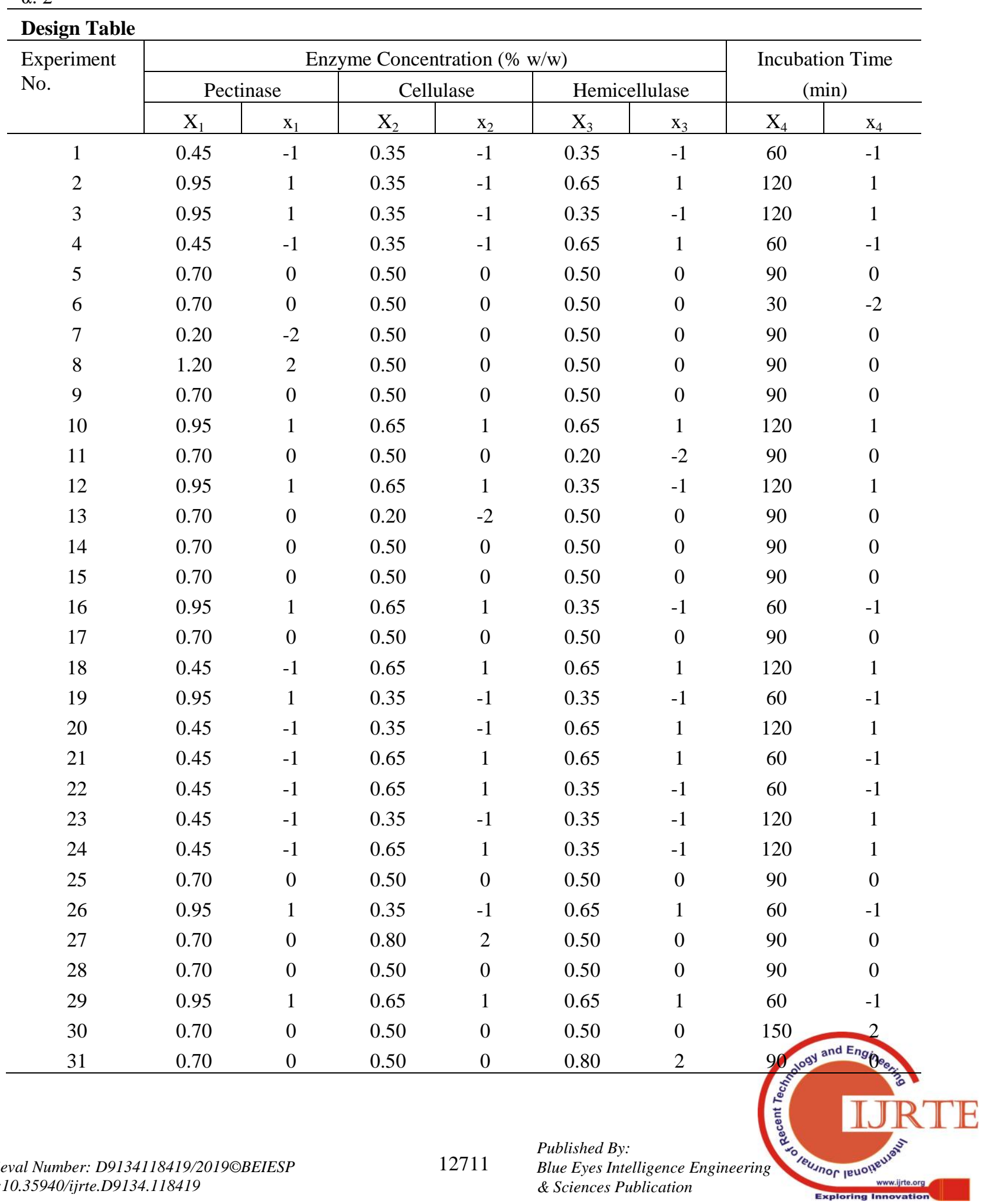




\section{RESULTS \& DISCUSSION}

The juice was first treated with each enzyme separately to study the effect and optimum process conditions for individual enzymes and then simultaneous treatment was given to juice based on the optimum conditions obtained for individual enzymes. Response surface methodology was used to obtain optimum for simultaneous treatment based on the range of concentration of enzymes and range of incubation time obtained during the experiments performed with individual enzymes.

\section{Optimization of enzyme reaction conditions for Pectinase} Effect of Enzyme Dose

For determination of optimum enzyme dose, the concentration of pectinase was varied starting from $0.10 \%$ (w/w), as shown in Table 2, at temperature of $55^{\circ} \mathrm{C}$ for $60 \mathrm{~min}$ of incubation. Table 2 shows the effect of pectinase concentration on juice turbidity and yield. On increasing the enzyme concentration, the turbidity of juice markedly decreased up to the enzyme concentration of $0.90 \%$ and remained constant thereafter. On increasing the enzyme concentration, the decrease in turbidity was due to decreased amount of pectin in the fruit juice, reducing the turbidity [45]. Alam et al. [43] also reported drastic decrease in turbidity by increasing pectinase enzyme concentration for clarification of carrot juice. Negative effect of pectinase concentration on turbidity was also reported by Guez et al. [46] for caja-manga (SpondiascythereaSonn.) pulp, making the juice clearer. Abdullah et al. [54] and Landbo et al. [47] also used pectinase for reduction in juice turbidity in carambola and elderberry juice. This variation in turbidity is because of the breakdown of protein molecules and formation of pectin-protein flocs which results in removal of colloidal suspension and leaves a clear supernatant [45]. In the same pattern, juice yield increased markedly with the increasing concentration of enzyme up to the corresponding enzyme concentration of $0.90 \%$ and remained almost constant thereafter. No juice was obtained from control and it was obtained as a highly viscous mass from the centrifuge. Akesowan et al. [25], Kaur et al. [28], Sevda et al. [26] reported the increase in clarity and yield on increasing pectinase enzyme concentration in guava juice. Based on these results, the optimum enzyme concentration was taken as $0.90 \%$. This optimum concentration value was used in next experiment for optimization of incubation time. These effects are graphically represented in Fig.2.

Table 2. Effect of pectinase concentration on papaya juice turbidity and yield

\begin{tabular}{cccc}
\hline $\begin{array}{c}\text { S. } \\
\text { N. }\end{array}$ & $\begin{array}{c}\text { Enzyme } \\
\text { Conc. } \\
(\% \text { w } / \mathrm{w})\end{array}$ & $\begin{array}{c}\text { Turbidity } \\
(\mathrm{NTU})\end{array}$ & $\begin{array}{c}\text { Yield } \\
(\%)\end{array}$ \\
\hline 1 & 0.10 & 311 & 54.1 \\
2 & 0.20 & 268 & 58.3 \\
3 & 0.30 & 240 & 61.8 \\
4 & 0.40 & 203 & 67.8 \\
5 & 0.50 & 160 & 74.0 \\
\hline
\end{tabular}

\begin{tabular}{cccc}
\hline 6 & 0.60 & 125 & 78.2 \\
7 & 0.70 & 125 & 78.8 \\
8 & 0.80 & 124 & 78.9 \\
9 & 0.90 & 123 & 79.2 \\
10 & 1.00 & 123 & 79.3 \\
11 & 1.20 & 123 & 79.3 \\
\hline
\end{tabular}

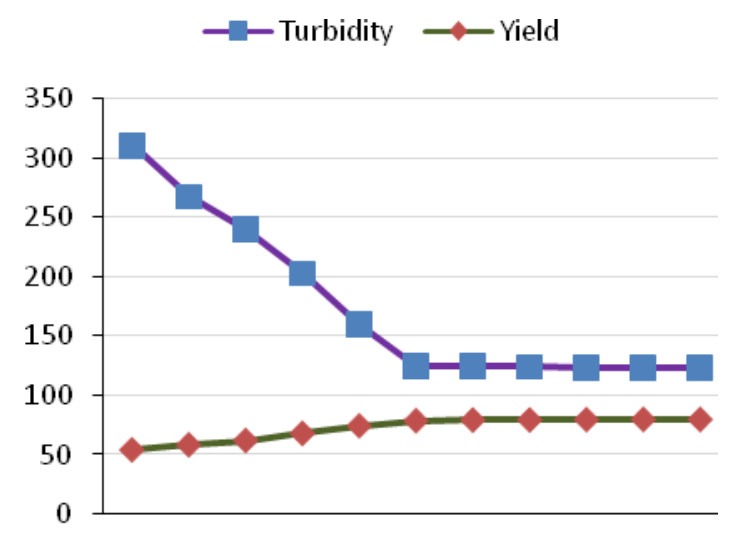

$\begin{array}{lllllllllll}0.1 & 0.2 & 0.3 & 0.4 & 0.5 & 0.6 & 0.7 & 0.8 & 0.9 & 1 & 1.2\end{array}$

Pectinase Concentration $(\% \mathrm{w} / \mathrm{w})$

Fig 2. Effect of pectinase concentration on papaya juice turbidity and yield

\section{Effect of Incubation Time}

The effect of varying incubation time (from $30 \mathrm{~min}$ to 150 min, as shown in Table 3) on the efficiency of pectinase was studied at a fixed enzyme dose of $0.90 \%(\mathrm{w} / \mathrm{w})$ and at temperature of $55{ }^{0} \mathrm{C}$. Table 3 shows the effect of incubation time on juice turbidity and yield. No significant changes in turbidity were observed on increasing the incubation period after 60 min of incubation. Yield was markedly increased at $60 \mathrm{~min}$ incubation time as compared to that at $30 \mathrm{~min}$ incubation and then a decrease was observed on and after 90 min incubation time. Based on these results 60 min time was taken as optimum. In Fig. 3, these effects are graphically represented.

Table 3. Effect of treatment time on pectinase treatment on papaya juice

\begin{tabular}{|c|c|c|c|c|}
\hline $\begin{array}{l}\text { S. } \\
\text { N. }\end{array}$ & $\begin{array}{l}\text { Enzyme } \\
\text { Conc. } \\
(\% \mathrm{w} / \mathrm{w})\end{array}$ & $\begin{array}{l}\text { Time } \\
\text { (min.) }\end{array}$ & $\begin{array}{c}\text { Turbidity } \\
\text { (NTU) }\end{array}$ & $\begin{array}{l}\text { Yield } \\
(\%)\end{array}$ \\
\hline 1 & 0.90 & 30 & 129 & 73.8 \\
\hline 2 & 0.90 & 60 & 123 & 79.2 \\
\hline 3 & 0.90 & 90 & 125 & 78.2 \\
\hline 4 & 0.90 & 120 & 126 & 72.7 \\
\hline 5 & 0.90 & 150 & 126 & 72.6 \\
\hline
\end{tabular}




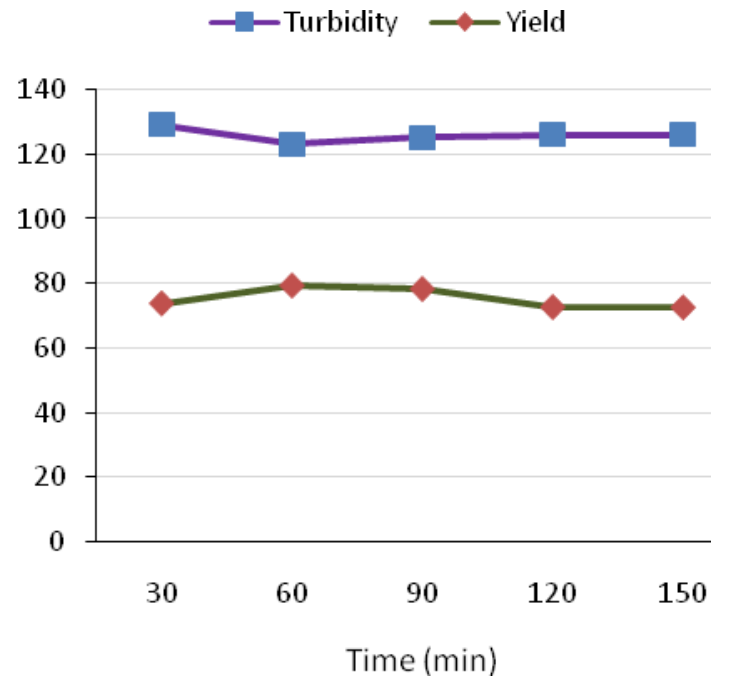

Fig 3. Effect of incubation time on pectinase treatment on papaya juice

\section{Optimization of enzyme reaction conditions for Cellulase} Effect of Enzyme Dose

To determine the optimum enzyme dose for cellulase, the concentration of cellulase was varied starting from $0.10 \%$ (w/w), as shown in Table 4, at temperature of $55^{\circ} \mathrm{C}$ for $60 \mathrm{~min}$ of incubation. Table 4 shows the effect of cellulase concentration on juice turbidity and yield. The turbidity of juice was found very high (more than $1000 \mathrm{NTU}$ ) for each dose. But cellulase showed significant effect on juice yield. Juice yield increased markedly with the increasing concentration of enzyme up to the corresponding enzyme concentration of $0.40 \%$, and a decrease was observed thereafter. Jori et al. [56] studied the effect of combined treatment of pectinase and cellulase on blended pulp of pineapple and mango. They found increase in clarity and yield on increasing the enzyme concentration. Also the juice clarity and yield were found more sensitive with respect to cellulase. Using the enzymatic pool of Cellulase FNC-1, Sreenath et al. [38] recovered up to 86 per cent pineapple juice by treating with pectinase and cellulase. Based on these results the optimum enzyme concentration was taken as $0.40 \%$. This optimum value was used in next experiment for optimizing incubation time. Effect of cellulase concentration on yield of papaya juice is graphically represented in Fig.4.

Table 4. Effect of cellulase concentration on papaya juice turbidity and yield

\begin{tabular}{cccc}
\hline $\begin{array}{c}\text { S. } \\
\text { N. }\end{array}$ & $\begin{array}{c}\text { Enzyme } \\
\text { Conc. } \\
(\% \mathrm{w} / \mathrm{w})\end{array}$ & $\begin{array}{c}\text { Turbidity } \\
(\mathrm{NTU})\end{array}$ & $\begin{array}{c}\text { Yield } \\
(\%)\end{array}$ \\
\hline 1 & 0.10 & $>1000$ & 55.6 \\
2 & 0.20 & $>1000$ & 58.2 \\
3 & 0.30 & $>1000$ & 64.0 \\
4 & 0.40 & $>1000$ & 70.5 \\
5 & 0.50 & $>1000$ & 70.3 \\
6 & 0.60 & $>1000$ & 70.1 \\
\hline
\end{tabular}

\begin{tabular}{llll}
\hline 7 & 0.70 & $>1000$ & 68.4 \\
8 & 0.80 & $>1000$ & 67.2 \\
\hline
\end{tabular}

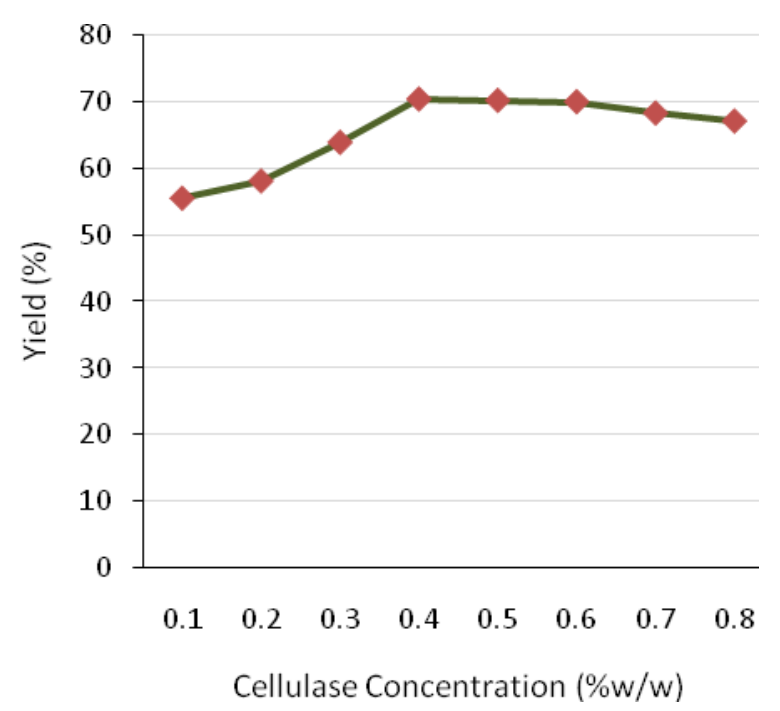

Fig 4. Effect of cellulase concentration on yield of papaya juice

\section{Effect of Incubation Time}

The effect of varying incubation time (from $30 \mathrm{~min}$ to 150 min, as shown in Table 5) on the efficiency of cellulase was studied at a fixed enzyme dose of $0.40 \%$ (w/w) and at temperature of $55{ }^{0} \mathrm{C}$. Table 5 shows the effect of incubation time on juice turbidity and yield. As observed in the previous experiment, the turbidity of juice obtained was found more than 1000 NTU. Yield was found maximum (72.9\%) at the corresponding incubation time of $90 \mathrm{~min}$. Based on these results the optimum incubation time was taken as $90 \mathrm{~min}$. In Fig. 5., effect of incubation time on cellulase treatment on papaya juice yield is graphically represented.

Table 5. Effect of incubation time on cellulase treatment on papaya juice

\begin{tabular}{ccccc}
\hline $\begin{array}{c}\text { S. } \\
\text { N. }\end{array}$ & $\begin{array}{c}\text { Enzyme } \\
\text { Conc. } \\
(\% \mathrm{w} / \mathrm{w})\end{array}$ & $\begin{array}{c}\text { Time } \\
(\mathrm{min} .)\end{array}$ & $\begin{array}{c}\text { Turbidity } \\
(\mathrm{NTU})\end{array}$ & $\begin{array}{c}\text { Yield } \\
(\%)\end{array}$ \\
\hline 1 & 0.40 & 30 & $>1000$ & 64.2 \\
2 & 0.40 & 60 & $>1000$ & 69.5 \\
3 & 0.40 & 90 & $>1000$ & 72.9 \\
4 & 0.40 & 120 & $>1000$ & 65.8 \\
5 & 0.40 & 150 & $>1000$ & 58.9 \\
\hline
\end{tabular}




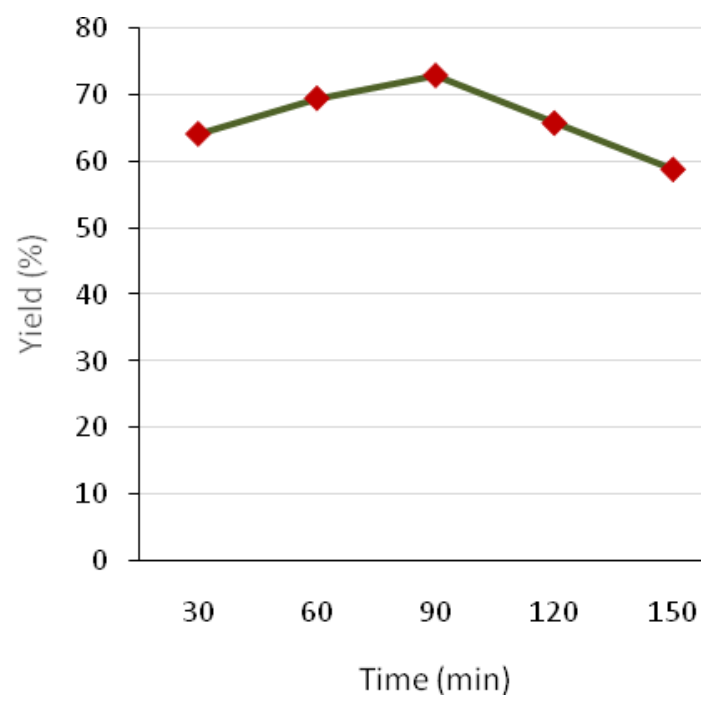

Fig 5. Effect of incubation time on cellulase treatment on papaya juice yield

Optimization of enzyme reaction conditions for Hemicellulase

\section{Effect of Enzyme Dose}

To determine the optimum enzyme dose for hemicellulase, the concentration of hemicellulase was varied starting from $0.10 \%$ (w/w), as shown in Table 6 , at temperature of $55^{\circ} \mathrm{C}$ for 60 min of incubation. Treatment with hemicellulase alone did not yield juice from papaya juice but resulted in a very thick and viscous mass. Therefore, hemicellulase was taken along with $0.1 \%$ cellulase for optimization experiments. Table 6 shows the effect of hemicellulase concentration on juice turbidity and yield. The turbidity of juice was found very high as it was found with cellulase (more than 1000 NTU). There was slight but continuous increase in juice yield on increasing enzyme concentration with the maximum value of $59.5 \%$ at the corresponding enzyme dose of $0.05 \%$. Juice yield remained almost constant thereafter. Therefore, the hemicellulase concentration $0.50 \%$ is taken for further determination of the optimum incubation time. Effect of hemicellulase (with cellulase $0.1 \%$ ) concentration on papaya juice yield is graphically represented in Fig.6. Thus cellulase and hemicellulase both were not able to decrease the turbidity value below 1000 NTU, but cellulase affected the juice yield significantly.

Table 6. Effect of hemicellulase (with cellulase $0.1 \%$ ) concentration on papaya juice turbidity and yield

\begin{tabular}{cccc}
\hline $\begin{array}{c}\text { S. } \\
\text { N. }\end{array}$ & $\begin{array}{c}\text { Enzyme } \\
\text { Conc. } \\
(\% \mathrm{w} / \mathrm{w})\end{array}$ & $\begin{array}{c}\text { Turbidity } \\
(\mathrm{NTU})\end{array}$ & $\begin{array}{c}\text { Yield } \\
(\%)\end{array}$ \\
\hline 1 & 0.00 & $>1000$ & 56.1 \\
2 & 0.10 & $>1000$ & 56.5 \\
3 & 0.20 & $>1000$ & 57.8 \\
4 & 0.30 & $>1000$ & 58.6 \\
5 & 0.40 & $>1000$ & 59.1 \\
6 & 0.50 & $>1000$ & 59.5 \\
\hline
\end{tabular}

\begin{tabular}{llll}
\hline 7 & 0.60 & $>1000$ & 59.4 \\
8 & 0.70 & $>1000$ & 59.5 \\
9 & 0.80 & $>1000$ & 59.5 \\
\hline
\end{tabular}

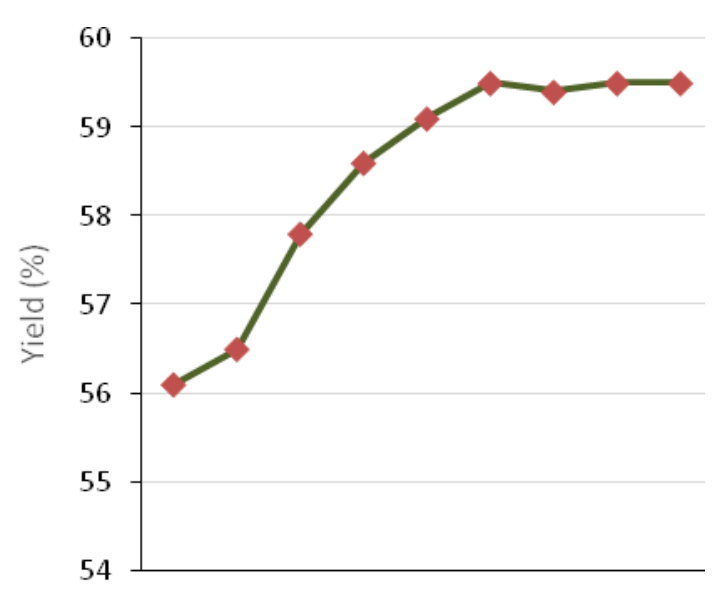

$\begin{array}{lllllllll}0 & 0.1 & 0.2 & 0.3 & 0.4 & 0.5 & 0.6 & 0.7 & 0.8\end{array}$

Hemicellulase Concentration (\%w/w)

Fig 6. Effect of hemicellulase (with cellulase $0.1 \%$ ) concentration on papaya juice yield

\section{Effect of Incubation Time}

The effect of varying incubation time (from $30 \mathrm{~min}$ to 150 min, as shown in Table 7) on the efficiency of hemicellulase was studied at a fixed enzyme dose of $0.50 \%(\mathrm{w} / \mathrm{w})$ with $0.1 \%$ cellulase and at temperature of $55^{\circ} \mathrm{C}$. Table 7 shows the effect of incubation time on juice turbidity and yield. The turbidity values are more than $1000 \mathrm{NTU}$ at each incubation time. The yield increased markedly up to the corresponding incubation period of $90 \mathrm{~min}$ and increased slightly thereafter. Based on these results the optimum value for incubation time was taken as 90 min. In Fig. 7, effect of incubation time on hemicellulase (with cellulase $0.1 \%$ ) treatment on papaya juice yield is graphically represented.

Table 7. Effect of incubation time on hemicellulase (with cellulase $0.1 \%$ ) treatment on papaya juice

\begin{tabular}{ccccc}
\hline $\begin{array}{c}\text { S. } \\
\text { N. }\end{array}$ & $\begin{array}{c}\text { Enzyme } \\
\text { Conc. } \\
(\% \mathrm{w} / \mathrm{w})\end{array}$ & $\begin{array}{c}\text { Time } \\
(\mathrm{min} .)\end{array}$ & $\begin{array}{c}\text { Turbidity } \\
(\mathrm{NTU})\end{array}$ & $\begin{array}{c}\text { Yield } \\
(\%)\end{array}$ \\
\hline 1 & 0.50 & 30 & $>1000$ & 49.2 \\
2 & 0.50 & 60 & $>1000$ & 59.6 \\
3 & 0.50 & 90 & $>1000$ & 61.3 \\
4 & 0.50 & 120 & $>1000$ & 61.5 \\
5 & 0.50 & 150 & $>1000$ & 61.5 \\
\hline
\end{tabular}




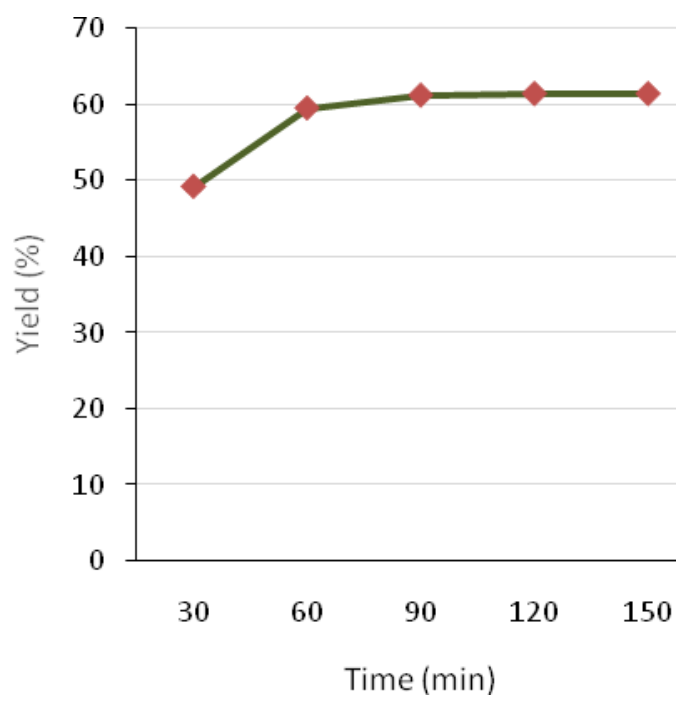

Fig. 7. Effect of incubation time on hemicellulase (with cellulase $0.1 \%$ ) treatment on papaya juice yield

Effect of simultaneous treatment of fruit juice with Pectinase, Cellulase and Hemicellulase

The optimum enzyme reaction conditions were obtained from the above experiments for the three enzymes separately. The optimum reaction conditions obtained for pectinase, were $0.90 \%$ enzyme concentration and $60 \mathrm{~min}$ incubation time. The optimum reaction conditions obtained for cellulase and hemicellulase, were $0.40 \%$ enzyme concentration with $90 \mathrm{~min}$ incubation time and $0.50 \%$ enzyme concentration with $90 \mathrm{~min}$ incubation time respectively. The compromised optimum treatment conditions were taken as Pectinase $0.90 \%$, Cellulase $0.40 \%$, Hemicellulase $0.50 \%$ with $90 \mathrm{~min}$ incubation time at a temperature of $55{ }^{\circ} \mathrm{C}$. The effect of treating the fruit juice simultaneously with all the three enzymes is shown in Table 8 . The fruit juice without addition of enzyme was taken as control.

Table 8. Effect of treatment of fruit juice with optimized conditions of pectinase, cellulase and hemicellulase simultaneously.

\begin{tabular}{lcc}
\hline & Control & Test \\
\hline Enzyme Concentration $(\%$ & & \\
w/w) & 0 & 0.90 \\
Pectinase & 0 & 0.40 \\
Cellulase & 0 & 0.50 \\
Hemicellulase & & \\
Incubation Temperature & 55 & 55 \\
$\left({ }^{0} \mathrm{C}\right)$ & & 90 \\
Incubation Time (min) & 90 & 90 \\
\hline
\end{tabular}

\begin{tabular}{llc}
\hline Results & & \\
\hline Turbidity (NTU) & $\begin{array}{c}\text { A thick and } \\
\text { highly } \\
\text { viscous mass }\end{array}$ & 11 \\
Yield (\%) & was obtained & 77.4 \\
\hline
\end{tabular}

Simultaneous treatment of papaya juice with pectinase, cellulase and hemicellulase produced clarified juice with turbidity $11 \mathrm{NTU}$ and yield $77.4 \%$. No juice is obtained without the addition of enzyme in fruit juice, but it produced only a thick and highly viscous mass. Shah and Nath [30] found significant increase of clarity and yield in litchi juice by multi-enzyme treatment of pectinase, cellulase and hemicellulase.

\section{Response Surface Optimization}

The experimental results on the effect of the independent variables (concentrations of pectinase, cellulase and hemicellulase enzymes and incubation time) on the responses (turbidity and juice yield) are shown in Table 9. The regression coefficients and $\mathrm{R}^{2}$ values for second order polynomial equation are shown in Table 10 for the responses. The adequacy and fitness of these equations were tested by ANOVA (analysis of variance) [48]. Analysis of Variance of regression models for responses is presented in Table 11. It suggests that linear and quadratic terms contribute significantly to the models for almost all responses. The values of $\mathrm{R}^{2}$ for turbidity and yield were 97.06 and 92.13 respectively. The $\mathrm{R}^{2}$ value close to $100 \%$ suggests that the model was fitted to the actual data. Therefore, the analysis of variance shows that the predicted $2^{\text {nd }}$ - order models are statistically valid. 
International Journal of Recent Technology and Engineering (IJRTE)

ISSN: 2277-3878, Volume-8, Issue-4, November 2019

Table 9: Responses for clarified papaya juice during RSM optimization studies

\begin{tabular}{|c|c|c|c|c|c|c|}
\hline \multirow{4}{*}{$\begin{array}{l}\text { Experiment } \\
\text { No. }\end{array}$} & \multicolumn{4}{|c|}{$\begin{array}{rr}\text { Factors } \\
\end{array}$} & \multicolumn{2}{|c|}{ Responses } \\
\hline & \multicolumn{3}{|c|}{ Enzyme Concentration } & \multirow[t]{2}{*}{ Incubation Time } & \multirow[t]{2}{*}{ Turbidity } & \multirow[t]{2}{*}{ Yield } \\
\hline & Pectinase & Cellulase & Hemicellulase & & & \\
\hline & $(\% \mathrm{w} / \mathrm{w})$ & $(\% \mathrm{w} / \mathrm{w})$ & $(\% \mathrm{w} / \mathrm{w})$ & $(\min )$ & (NTU) & $(\%)$ \\
\hline 1 & 0.45 & 0.35 & 0.35 & 60 & 15 & 71.8 \\
\hline 2 & 0.95 & 0.35 & 0.65 & 120 & 10 & 73.1 \\
\hline 3 & 0.95 & 0.35 & 0.35 & 120 & 10 & 72.8 \\
\hline 4 & 0.45 & 0.35 & 0.65 & 60 & 15 & 72.1 \\
\hline 5 & 0.70 & 0.50 & 0.50 & 90 & 11 & 78.4 \\
\hline 6 & 0.70 & 0.50 & 0.50 & 30 & 11 & 69.5 \\
\hline 7 & 0.20 & 0.50 & 0.50 & 90 & 23 & 70.9 \\
\hline 8 & 1.20 & 0.50 & 0.50 & 90 & 11 & 78.6 \\
\hline 9 & 0.70 & 0.50 & 0.50 & 90 & 10 & 78.5 \\
\hline 10 & 0.95 & 0.65 & 0.65 & 120 & 10 & 74.0 \\
\hline 11 & 0.70 & 0.50 & 0.20 & 90 & 11 & 78.1 \\
\hline 12 & 0.95 & 0.65 & 0.35 & 120 & 10 & 73.6 \\
\hline 13 & 0.70 & 0.20 & 0.50 & 90 & 11 & 73.8 \\
\hline 14 & 0.70 & 0.50 & 0.50 & 90 & 11 & 78.3 \\
\hline 15 & 0.70 & 0.50 & 0.50 & 90 & 12 & 78.4 \\
\hline 16 & 0.95 & 0.65 & 0.35 & 60 & 10 & 75.7 \\
\hline 17 & 0.70 & 0.50 & 0.50 & 90 & 10 & 78.4 \\
\hline 18 & 0.45 & 0.65 & 0.65 & 120 & 15 & 71.1 \\
\hline 19 & 0.95 & 0.35 & 0.35 & 60 & 10 & 74.8 \\
\hline 20 & 0.45 & 0.35 & 0.65 & 120 & 15 & 70.3 \\
\hline 21 & 0.45 & 0.65 & 0.65 & 60 & 15 & 72.9 \\
\hline 22 & 0.45 & 0.65 & 0.35 & 60 & 15 & 72.7 \\
\hline 23 & 0.45 & 0.35 & 0.35 & 120 & 15 & 70.0 \\
\hline 24 & 0.45 & 0.65 & 0.35 & 120 & 15 & 70.8 \\
\hline 25 & 0.70 & 0.50 & 0.50 & 90 & 11 & 78.5 \\
\hline 26 & 0.95 & 0.35 & 0.65 & 60 & 10 & 75.1 \\
\hline 27 & 0.70 & 0.80 & 0.50 & 90 & 11 & 77.2 \\
\hline 28 & 0.70 & 0.50 & 0.50 & 90 & 10 & 78.4 \\
\hline 29 & 0.95 & 0.65 & 0.65 & 60 & 10 & 76.0 \\
\hline 30 & 0.70 & 0.50 & 0.50 & 150 & 11 & 70.3 \\
\hline 31 & 0.70 & 0.50 & 0.80 & 90 & 11 & 78.7 \\
\hline
\end{tabular}

Table 10: Regression Coefficients and $R^{2}$ values for dependent variables for Papaya

\begin{tabular}{cccc}
\hline Term & $\begin{array}{c}\text { Regression } \\
\text { Coefficient }\end{array}$ & Turbidity (NTU) & Yield \% \\
\hline Constant & $\mathrm{b}_{0}$ & $10.572^{*}$ & $78.431^{*}$ \\
x1 & $\mathrm{b}_{1}$ & $-2.681^{*}$ & $1.623^{*}$ \\
x2 & $\mathrm{b}_{2}$ & 0.000 & $0.579^{* * *}$ \\
x3 & $\mathrm{b}_{3}$ & 0.000 & 0.153 \\
x4 & $\mathrm{b}_{4}$ & 0.014 & $-0.577^{* * *}$ \\
x1.x1 & $\mathrm{b}_{11}$ & $1.639 *$ & $-1.213^{*}$ \\
x2.x2 & $\mathrm{b}_{22}$ & 0.138 & $-1.016^{*}$ \\
x3.x3 & $\mathrm{b}_{33}$ & 0.138 & -0.285 \\
x4.x4 & $\mathrm{b}_{44}$ & 0.138 & $-2.419^{*}$ \\
x1.x2 & $\mathrm{b}_{12}$ & 0.000 & 0.000 \\
x1.x3 & $\mathrm{b}_{13}$ & 0.000 & 0.000 \\
x1.x4 & $\mathrm{b}_{14}$ & 0.000 & -0.055 \\
x2.x3 & $\mathrm{b}_{23}$ & 0.000 & 0.000 \\
x2.x4 & $\mathrm{b}_{24}$ & 0.000 & -0.009 \\
x3.x4 & $\mathrm{b}_{34}$ & 0.000 & 0.009 \\
\hline $\mathrm{R}{ }^{2}$ & & 97.06 & 92.13 \\
\hline
\end{tabular}

\footnotetext{
* Significant at 0.001 level

** Significant at 0.01 level

*** Significant at 0.05 level
} 
Table 11: Analysis of Variance (ANOVA) for $2^{\text {nd }}$ Order Model

\begin{tabular}{l|c|c|c|c|c}
\hline \multirow{2}{*}{ Source } & \multirow{2}{*}{ DF } & \multicolumn{2}{|c|}{ Turbidity } & \multicolumn{2}{c}{ Juice Yield } \\
\cline { 3 - 6 } & & $\begin{array}{c}\text { Adj Sum of } \\
\text { Squares }\end{array}$ & P Value & $\begin{array}{c}\text { Adj Sum of } \\
\text { Squares }\end{array}$ & P Value \\
\hline Model & 14 & 249.449 & $<0.001$ & 287.050 & $<0.001$ \\
Linear & 4 & 172.511 & $<0.001$ & 79.825 & $<0.001$ \\
Square & 4 & 76.938 & $<0.001$ & 207.174 & $<0.001$ \\
2-Way & 6 & 0.000 & 1.000 & 0.051 & 1.000 \\
Interaction & 16 & & & & \\
Error & 10 & 4.548 & - & 24.532 & - \\
Lack-of-Fit & 6 & 3.048 & 0.588 & 24.491 & $<0.001$ \\
Pure Error & 30 & 256.998 & - & 0.040 & - \\
Total & - & $97.06 \%$ & - & 311.582 & - \\
$\mathrm{R}^{2}$ & - & $94.49 \%$ & - & $92.13 \%$ & - \\
$\mathrm{R}^{2}$ (adj) & & & & $85.24 \%$ & - \\
\hline
\end{tabular}

\section{Turbidity}

Juice turbidity was significantly affected $(\mathrm{p} \leq 0.001)$ by pectinase concentration but not by cellulase and hemicellulase concentration (Table 10) as also observed in individual enzyme experiments. From the table it was observed that for pectinase concentration turbidity has a negative linear effect and a positive effect at quadratic level (significant at $p \leq 0.001$ ). No effect either linear or quadratic level were observed for cellulase and hemicellulase concentration. Also, there was no interaction found among the variables for juice turbidity. The value of turbidity indicates unsettled matter or impurities in water suspension, e.g. colloidal polysaccharide particles in juices [49].A juice that is to be marketed as clear should have no turbidity or no unstable cloud which is considered "muddy", otherwise it will not be acceptable to be marketed [50]. The decrease in turbidity on increasing pectinase concentration was also reported by Alam et al. [43] for carrot juice, Karangwa et al. [51] for blended carrot-orange juice, Vinjamuri and Bhavikatti [52] for mixed fruit juices, Umsza-Guez et al. [53] for caja-manga pulp, Abdullah et al. [54] for carambola fruit juice and Sin et al. [55] for sapodilla juice. The effect of experimental variables (Pectinase enzyme concentration and incubation time) on papaya juice turbidity is shown in Fig 8 as response surface and contour plots generated from fitted model. The application of response surface methodology yielded following regression model (without non-significant terms), which is empirical relation between response (juice turbidity) and the test variables in coded units:

Turbidity (NTU) $=10.572^{\dagger}-2.681 \times 1^{\dagger}+1.639 \times 1 * \times 11^{\dagger}$

${ }^{\dagger}$ Significant at 0.001 level

${ }^{\dagger}$ Significant at 0.01 level

${ }^{\dagger}$ Significant at 0.05 level

\section{Juice Yield}

From Table 10 it is clear that the papaya juice yield was significantly affected by concentration of enzymes at first order and a positive effect was observed $(p \leq 0.05)$ except hemicellulase. Yield was also found to be effected by all the variables except hemicellulase concentration at second order but a negative effect was observed (significant at $p \leq 0.001$ ). Interaction effects were not found significant for juice yield also. Sreenath and Santhanam [15] also reported the improvement in papaya juice yield after treatment with pectinase and cellulase enzyme. Effect of enzyme(s) concentration and incubation period on yield is shown in Fig 9a-9c as response surface and contour plots generated from fitted model. The following regression model (without non-significant terms) was obtained by the application of response surface methodology, which shows empirical relation between response (juice yield) and the test variables in coded units: RSM showed no significant role of hemicellulase either on juice turbidity or yield.

$$
\begin{aligned}
& { }_{\text {Significant at } 0.001 \text { level }} \\
& { }^{\dagger} \text { Significant at } 0.01 \text { level } \\
& { }^{\dagger} \text { Significant at } 0.05 \text { level }
\end{aligned}
$$$$
\text { Yield }(\%)=78.431^{\dagger}+1.623 \times 1^{\dagger}+0.579 \times 2^{\dagger \dagger}
$$$$
-0.577 \times 4^{\dagger \dagger}-1.213 \times 1 * x 1^{\dagger}-1.016 \times 2 * \times 2^{\dagger}
$$$$
-2.419 \times 4 * x 4^{\dagger}
$$

The effect of multienzyme treatment on juice clarity and yield was also studied by Shah and Nath [30] for litchis. He reported clarity and juice yield as a function of linear and quadratic effects of concentrations of the enzymes pectinase, cellulase, hemicellulase and incubation time. Jori et al. [56] showed the effects of multienzyme: pectinase and cellulase treatment for blended pineapple and mango pulp clarification. Koffi et al, [24] reported the effect of different combinations of all these three enzymes in reducing viscosity and improving filterability of green and ripe banana purees. 
Surface Plot of Turbity (NTU) vs Incubation Time, Pectinase Conc

Fig 8: Surface and Contour plots showing interaction of Juice Turbidity with enzyme (Pectinase) concentration and incubation time
Surface Plot of Yield (\%) vs Incubation Time, Pectinase Conc.

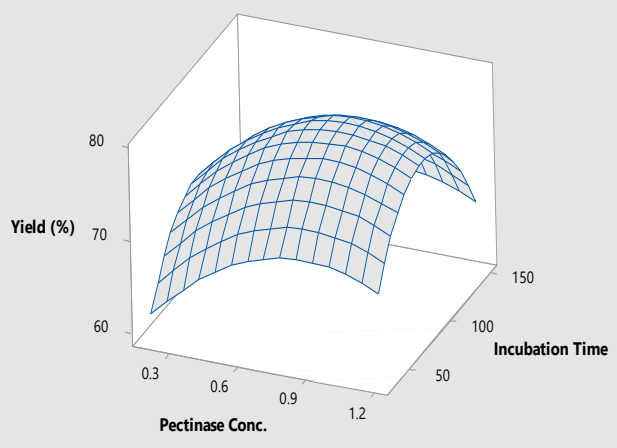

Contour Plot of Turbity (NTU) vs Incubation Time, Pectinase Conc.

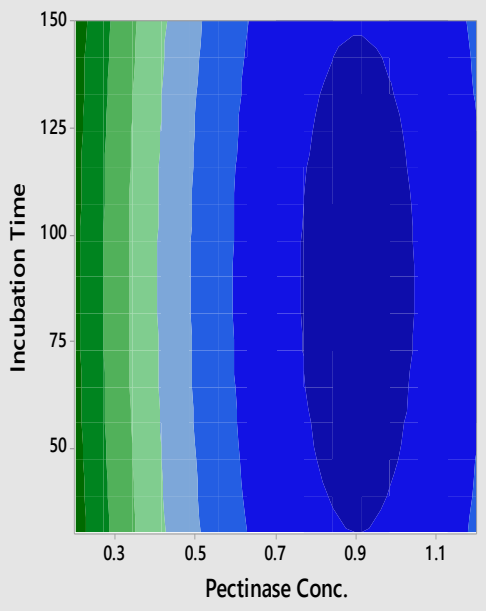

(a)
Contour Plot of Yield (\%) vs Incubation Time, Pectinase Conc.

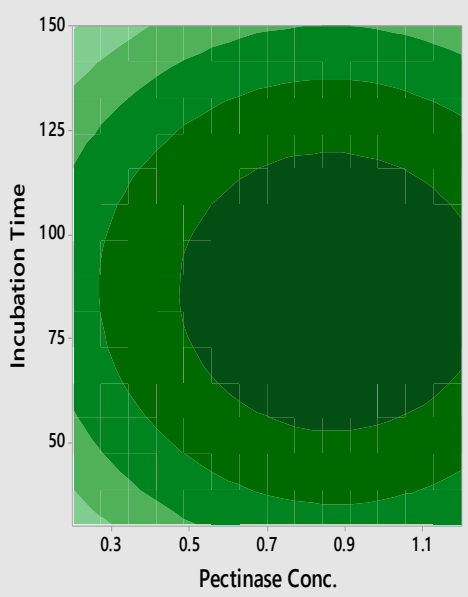

Yield (\%)

$<60$
$60-64$

$60-64$
$64-68$

$64-68$
$68-72$
$72-76$

$68-72$
$72-76$

$>76$
Hold Values Cellulase Conc. $\quad 0.5$ Hemicellulase Conc. 0.5
Contour Plot of Yield (\%) vs Incubation Time, Cellulase Conc.

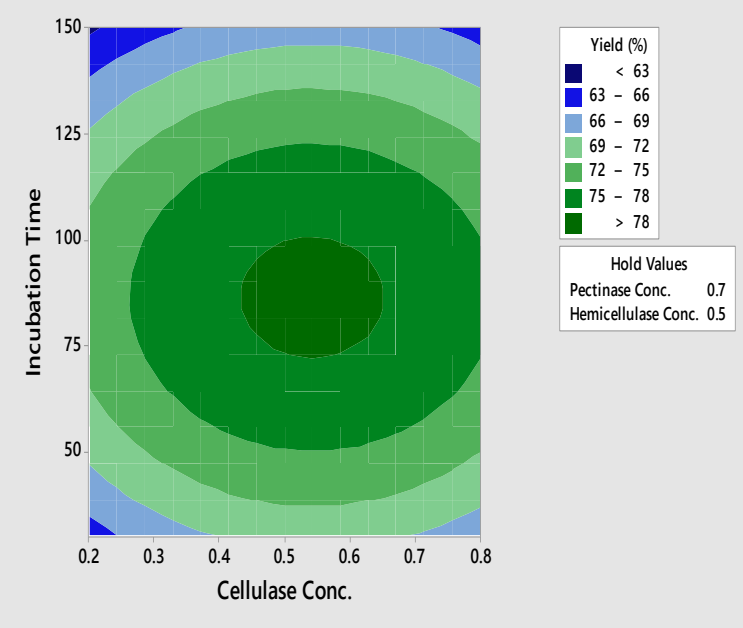

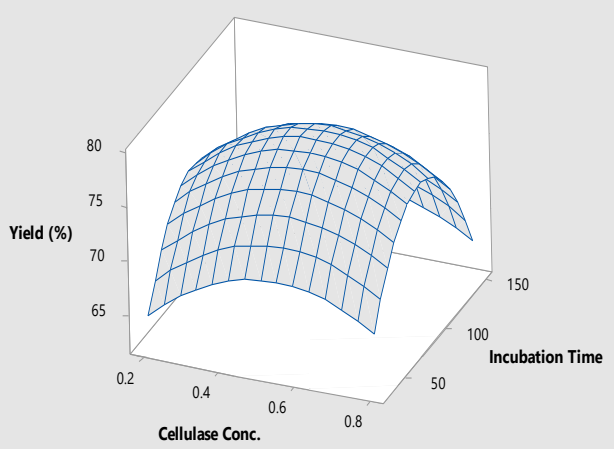

Surface Plot of Yield (\%) vs Incubation Time, Cellulase Conc.

(b) 
Effect of Multi-enzyme (Pectinase, Cellulase and Hemicellulase) Treatment on Clarification of Papaya (Carica papaya) Fruit Juice

Surface Plot of Yield (\%) vs Incubation Time, Hemicellulase Conc.

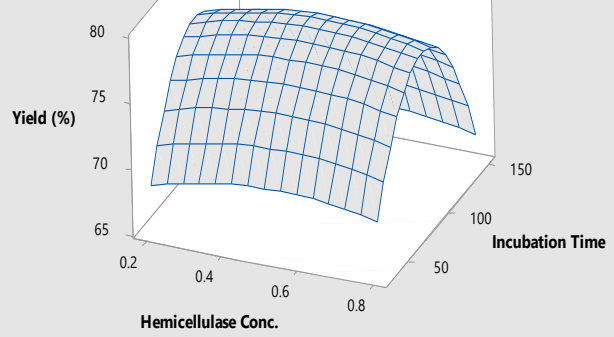

(c)

Contour Plot of Yield (\%) vs Incubation Time, Hemicellulase Conc.

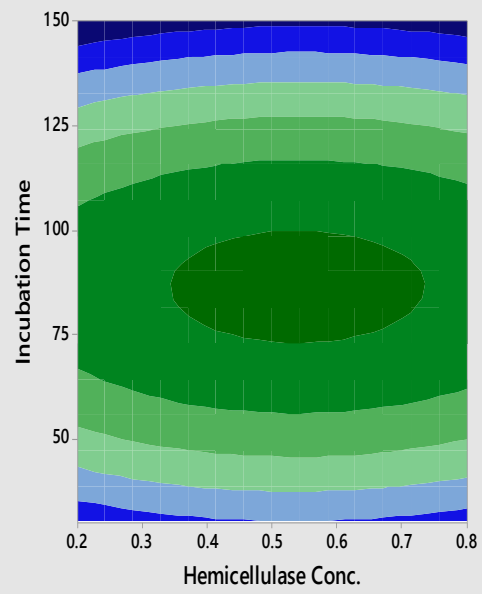

Yield (\%)

$<68$
$68-70$

$70-72$

$72-74$

$74-76$

$76-78$

$>78$

Pectinase Conc. 0.7 Cellulase Conc. 0.5

Fig 9 (a,b,c): Surface and Contour plots showing interaction of Juice Yield with enzyme (s) concentration and incubation time

\section{Multiple Response Optimizations}

For determining the overall optimum conditions in multi response situation of this study, a two-sided desirability function was used with the responses turbidity to be minimized and yield to be maximized (Table 12). Similar importance was given to both the responses. Table 13 shows the optimum parameters for multiple response turbidity and juice yield along with the predicted responses which are also shown in optimization plot (Fig 10). The optimization solution for multiple responses turbidity and juice yield showed treatment of papaya juice with $0.87 \%$ (w/w) pectinase, $0.50 \%(\mathrm{w} / \mathrm{w})$ cellulase and $0.50 \%(\mathrm{w} / \mathrm{w})$ hemicellulase for $86 \mathrm{~min}$ incubation time at $55^{\circ} \mathrm{C}$ with predicted values of turbidity 9.5 NTU and yield $79.01 \%$ and composite desirability as 1.0. These optimum conditions obtained from the response optimizer were very close to the compromised optimum conditions obtained for simultaneous treatment based on the optimum process conditions obtained for individual enzymes as shown in table 8 . When the juice was treated with the optimized set of process conditions obtained from response optimizer, the turbidity and juice yield were obtained as 9 and $78.8 \%$, which were in good agreement with the predicted values.

Table 12: Response Optimization Parameters in Response Optimizer:

\begin{tabular}{|c|c|c|c|c|c|c|}
\hline Response & Goal & Lower & Target & Upper & Weight & Importance \\
\hline Turbidity (NTU) & Minimum & & 10 & 23 & 1 & 1 \\
\hline Yield $(\%)$ & Maximum & 69.5 & 78.7 & & 1 & 1 \\
\hline \multicolumn{7}{|c|}{ Table 13: Solution (Uncoded Value) } \\
\hline \multicolumn{4}{|c|}{ Variables } & \multicolumn{2}{|c|}{$\begin{array}{c}\text { Multiple Response } \\
\text { Prediction }\end{array}$} & \multirow[t]{2}{*}{$\begin{array}{l}\text { Composite } \\
\text { Desirability }\end{array}$} \\
\hline $\begin{array}{c}\text { Pectinase } \\
\text { Concentration }\end{array}$ & $\begin{array}{c}\text { Cellulase } \\
\text { Concentration }\end{array}$ & $\begin{array}{l}\text { Hemicellulase } \\
\text { Concentration }\end{array}$ & $\begin{array}{l}\text { Incubation } \\
\text { Time }\end{array}$ & $\begin{array}{l}\text { Turbidity } \\
\text { (NTU) }\end{array}$ & $\begin{array}{c}\text { Yield } \\
(\%)\end{array}$ & \\
\hline 0.866667 & 0.5 & 0.5 & 85.7576 & 9.514 & 79.0127 & 1.0 \\
\hline
\end{tabular}

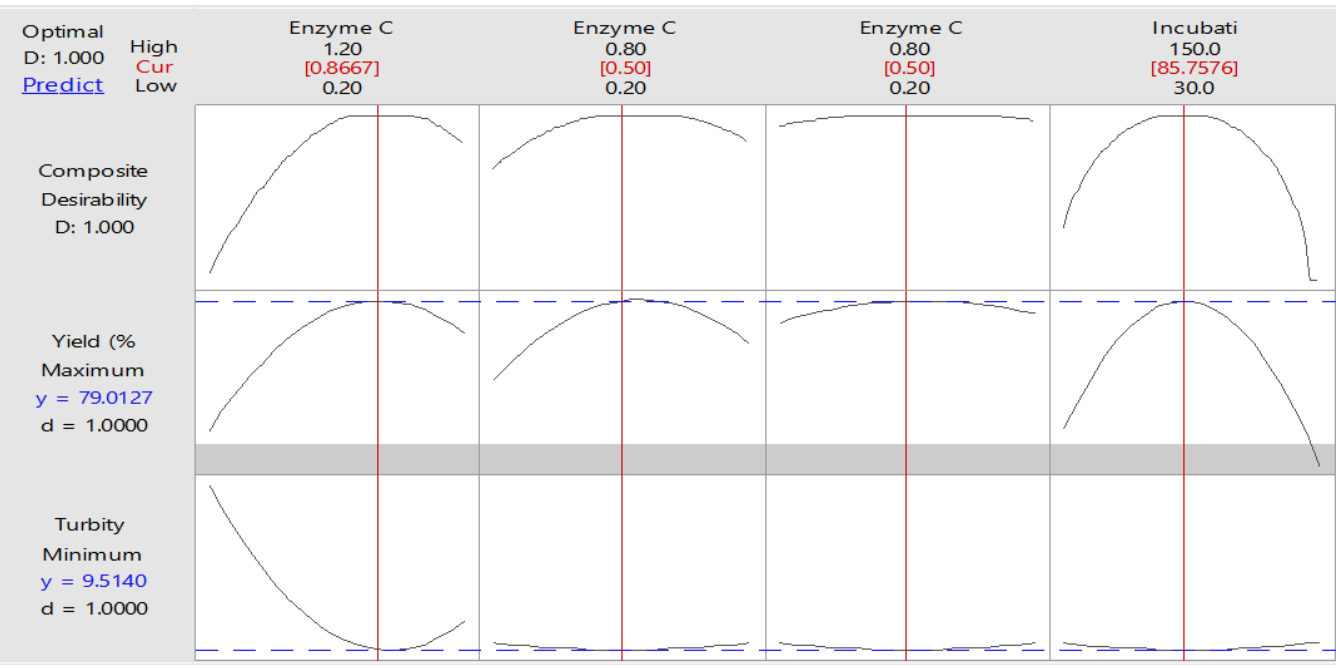

Fig. 10: Optimization Plot 


\section{CONCLUSION}

The study presented the effects of treatments of papaya juice with commercial enzymes pectinase, cellulase and hemicellulase individually as well as the effect of simultaneous treatment with all the three enzymes. The papaya juice turbidity and per cent yield improved significantly by simultaneous enzymatic treatment of the juice. The treatment of papaya juice with enzymes was effectively optimized using RSM with a four factor and five level CCRD which involved thirty-one experiments. Based on Response Surface Optimization, the recommended enzymatic clarification process conditions for simultaneous treatment of papaya juice was $0.87 \%, 0.50 \%$ and $0.50 \%$ enzyme concentration for enzymes Pectinase, Cellulase and Hemicellulase respectively, and incubation period of $86 \mathrm{~min}$ at incubation temperature of $55{ }^{\circ} \mathrm{C}$. Under these conditions, the clarified papaya juice obtained experimentally was of turbidity 9 NTU and $78.8 \%$ of yield.

\section{REFERENCES}

1. Evans, E.A. \& Ballen, F.H.,An Overview of Global Papaya Production, Trade and Consumption, UF/IFAS Extension, University of Florida, 2015, FE913.

2. APEDA, Fresh Fruits \& Vegetables. [online], Available at:http://apeda.gov.in/apedawebsite/six_head_product/FFV.htm [Accessed: 25 March 2019].

3. NHB, Papaya. [online], Available at: http://nhb.gov.in/Horticultur\%20Crops/Papaya/Papaya1.htm [Accessed: 01 April, 2017].

4. Shashikalabai, D., Kumar, K.A., Basavarajappa, R., Mavarkar, N.S. and Basavarajnaik, T., Processing for Value Addition of Papaya. International Journal of Tropical Agriculture, 34(3), 2016, pp.633-637.

5. Tu, T., Meng, K., Bai, Y, Shi, P., Luo, H., Wang, Y., Yang, P., Zhang, Y., Zhang, W. and Yao, B., High-yield production of a low-temperature-active polygalacturonase for papaya juice clarification. Food Chemistry, 141(3), 2013, pp.2974-2981.

6. Brito, B., Rodriguez, M., Samaniego, I., Jaramillo, M., and Vaillan, F., Characterizing polysaccharides in pure form and their enzymatic liquefaction. Food Research Technology, 2008, pp355-361.

7. Vaillant, F., Millan, A., Dornier, M., Decloux, M., and Reynes, M., Strategy for economical optimisation of the clarification of pulpy fruit juices using crossflow microfiltration. J. Food Eng., 48(1), 2001, pp.83-90.

8. Food \& Beverage News, Fruit juice market to grow at CAGR of $22 \%$ over five years. [online], Available at: http://www.fnbnews.com/Interview/fruit-juice-market-to-grow-a t-cagr-of-22-over-five-years-39501, 2016 [Accessed: 04 April 2017].

9. Grassin, C., and Fauquembergue, P., Fruit juices. Industrial Enzymology. Godfrey T, West S (eds),. MacMillan Press, London, UK, 1996, pp. $226-264$.

10. Béguin, P., and Daubert, J, P., The biological degradation of cellulose. FEMS Microbiol Rev., 13, 1994, pp. 25-58.

11. Henrissat, B., Cellulases and their Interaction with cellulose. In Cellulose.Vol. 1, 1994, pp. 169-196.

12. Sharma, H.P., Patel, H. \& Sharma, S., Enzymatic Extraction and Clarification of Juice from Various Fruits - A Review. Trends in Post Harvest Technology, 2(1), 2014, pp.01-14.

13. Pal, A., and Khanum, F., Efficacy of xylanase purified from Aspergillus niger DFR-5 alone and in combination with pectinase and cellulase to improve yield and clarity of pineapple juice. J Food Sci Technol., 2011, pp.560-568.

14. Dzogbefia, V. P. \& Djokoto, D. K., Combined effects of enzyme dosage and reaction time on papaya juice extraction with the aid of pectic enzymes - A preliminary report. Journal of Food Biochemistry, 30, 2006, pp. 117-122.

15. Sreenath, H.K., \& Santhanam, K., Comparison of cellulolytic and pectinolytic treatment of various fruit pulps. Chemie Mikrobiologie Technologie der Ledensmittel, 14, 1992, pp. 46-50.
16. Tapre, A.R. and Jain, R.K., Optimization of an enzyme assisted banana pulp clarification process. International Food Research Journal, 21(5), 2014, pp.2043-2048.

17. Sagu, T.S., Nso, J.E., Karmakar, S. and De, S.,Optimisation of low temperature extraction of banana juice using commercial pectinase. Food Chemistry, 151, 2014, pp.182-190.

18. Cheirsilp, B. \& Umsakul, K., Processing of banana-based wine product using pectinase and $\alpha$-amylase. Journal of Food Process Engineering, 31, 2008, pp.78-90.

19. Tadakittisarn, S., Haruthaithanasan, V., Chompreeda, P. and Suwonsichon, T., Optimization of pectinase enzyme liquefaction of banana "Gros Michel" for banana syrup production. Kasetsart Journal: Natural Science, 41(4), 2007, pp.740-750.

20. Lee, W.C., Yusof, S., Hamid, N.S.A. and Baharin, B.S., Optimizing conditions for enzymatic clarification of banana juice using response surface methodology (RSM). Journal of Food Engineering, 73(1), 2006, pp.55-63.

21. Yunchalad, M., Ai, J.M. and Surojanamethkul, V., Factors affecting the production of clarified banana drink. Kasetsart J. (Nat. Sci.), 29, 1995, pp. 231-238.

22. Kotecha, M. P., Adsule, R. N. and Kadam, S. S.,Preparation of wine from over-ripe banana fruits. Beverage Food World 21, 1994, pp28.

23. Pheantaveerat, A. \& Anprung, P., Effect of pectinases, cellulases and amylases on production of banana juice. Food, 23(3), 1993 pp.188-196.

24. Koffi, E.K., Sims, C.A. \& Bates, R.P., Viscosity reduction and prevention of browning in the preparation of clarified banana juice. Journal of Food Quality, 14, 1991, pp.209-218.

25. Akesowan, A. \& Choonhahirun, A., Effect of Enzyme Treatment on Guava Juice Production Using Response Surface Methodology. TheJournal of Animal and Plant Sciences, 23(1), 2013, pp.114-120.

26. Sevda, S., Singh, A., Joshi, C., Rodrigues, L., Extraction and Optimization of Guava Juice by Using Response Surface Methodology. American Journal of Food Technology, 7 (6), 2012, pp 326-329.

27. Thi Thuy Le, Vo Phu Thuan Nguyen, V.V.M.L.,Application of cellulase preparation to guava mash treatment in juice processing: optimization of treatment conditions by RSM. Asian Journal of Food and Agro-Industry, 5(4), 2012, pp.284-291.

28. Kaur, S., Sarkar, B.C., Sharma, H.K., and Singh, C., Response surface optimization of conditions for the clarification of guava fruit juice using commercial enzyme. Journal of Food Process Engineering, 34(4), 2011, pp.1298-1318.

29. Vijayanand, P., Kulkarni, S.G., and Prathibha, G.V., Effect of pectinase treatment and concentration of litchi juice on quality characteristics of litchi juice. Journal of Food Science and Technology, 47(2), 2010, pp. 235-239.

30. Shah, N.S. \& Nath, N., Optimization of an Enzyme Assisted Process for Juice Extraction and Clarification from Litchis (Litchi Chinensis Sonn.). International Journal of Food Engineering, 3(2), 2007.

31. Anuraha, K., Naga Padma, P., Venkateshwar, S. and Gopal Reddy, Mango juice clarification with polygalacturonase produced by Aspergillus awamori MTCC 9166 - Optimization of conditions. International Food Research Journal 23(1), 2016, pp. 147-151.

32. Ndiaye, C., Xu, S.Y., Wang, Z., Ndoye, A.S., Optimization of processing parameters for natural cloudy mango (Mangifera indica L.) juice using pectolytic and cellulolytic enzymes. Fruits, 66, 2011, pp. 291-303.

33. Vaidya, D., Vaidya, M., Sharma, S., and Ghanshyam, Enzymatic treatment for juice extraction and preparation and preliminary evaluation of kiwifruits wine. Natural Product Radiance, 8(4), 2009 , pp. 380-385

34. Dawes, H., Struebi, P. and Keene, J., Kiwifruit juice clarification using a fungal proteolytic enzyme. Journal of Food Science. 59(4), 1994, pp. 859-861.

35. Pilnik, W., Voragen, A. G. J. and de Vos, L, Enzymatishe Verflussingung vonobst und Gemuse. Fluss. Obst. 42(11), 1975 pp. 448-451.

36. Voragen, A.G.J., Heutink, R. and Pilnik, W., Solubilization of apple cell walls with polysaccharide degrading enzymes. $J$ Applied Biochemistry. 2, 1980, pp. 452-468.

37. Dzogbefia, V.P., Ameko, E., 
Oldham, J.H. and Ellis, W.O., Production and Use of Pectolytic Enzyme from Saccharomyces cerevisiae for the Extraction of Pineapple Juice. Food Biotechnology, 15(1), 2001,pp. 25-34.

38. Sreenath, H. K., Sudarshan Krishna, K. R. and Santhanam, K., Improvement of juice recovery from pine pulp residue using cellulases and pectinases. J. Ferment. and Bioengg., 78(6), 1994, pp. 486-488.

39. Chen, X., Xu, F., Qin, W., Ma, L., and Zheng, Y., Optimization of Enzymatic Clarification of Green Asparagus Juice Using Response Surface Methodology. Journal of Food Science, 77(6), 2012, pp. C665-C670.

40. Santin, M.,Treichel, H.,Valduga, E.,Cabral, L. MC and Luccio, M.D., Evaluation of enzymatic treatment of peach juice using response surface methodology. Journal of the Science of Food and Agriculture, 88, 2008, pp. 507-512.

41. Joshi, V,K, Parmar, M., and Rana, N., Purification and characterization of pectinase produced from apple pomace and evaluation of its efficiency in fruit juice extraction and clarification. Indian Journal ofNatural Products and Resources, 2(2), 2011, pp. 189-197.

42. Uzuner, S., and Cekmecelioglu, D., Optimizing clarification of carrot juice by bacterial crude pectinase. International Journal of Food Science and Technology, 50, 2015, pp. 2707-2712.

43. Alam, M.S., Ahuja, G., Gupta, K., Enzymatic clarification of carrot juice by using response surface methodology. Agric Eng Int: CIGR Journal, 16(3), 2014, pp. 173-179.

44. Chang, T., Siddiq, M., Sinha, N. K. and Cash, J. N.,Commercial pectinases and the yield and quality of Stanley plum juice. Journal of Food Processing and Preservation, 19, 1995 , pp.89-101.

45. Alvarez, S., Alvarez, R, Riera, F.A. and Coca, J., Influence of depectinization on apple juice ultrafiltration. Colloids and Surfaces A: Physiochemical and Engineering Aspects, 138 (2-3), 1998, pp. 377-382.

46. Guez, M.A.U., Rinaldi, R., Vanzela, E.S.L., Martin, N., Silva, R.D., Gomes, E., and Thomeo. J.C., Effect of Pectinolitic enzymes on the physical properties of caja-manga (SpondiascynthereaSonn.) Pulp. Cienc. Tecnol. Aliment., Campinas, 31(2), 2011, pp. 517-526.

47. Landbo, A.K. Kaack, K., Meyer, A.S., Statistically designed two step response surface optimization of enzymatic prepress treatment to increase juice yield and lower turbidity of elderberry juice. Innovative Food Science Emerging Technology, 8, pp. 135-142.

48. Khuri, A. I. and Cornell, J. A., Response surfaces: designs and analyses; Marcel Dekker, New York, USA, 1989.

49. Grassin, C.; Fauquembergue. P., Enzymes, Fruit Juice Processing. In Flickinger, M. C.; Drew, S. W. (Eds.). Encyclopedia ofbioprocess technology, fermentation, biocatalysis, bioseparation. New York: John Wiley and Sons, Inc., 1999.

50. Floribeth, V., Celsa, L., \& Cooke, R. D., A study of the production of clarified banana juice using pectinolytic enzymes. Food Technology, 16, 1981, pp. 115-125.

51. E. Karangwa, H., Khizar, L., Rao, D.S., Nshimiyimana, M.B.K., Foh, L., Li, S.Q., Xia and Zhang, X.M., Optimization of Processing Parameters for Clarification of Blended Carrot-orange Juice and Improvement of its Carotene Content. Advance Journal of Food Science and Technology 2(5), 2010, pp 268-278.

52. Vinjamuri, S. and Bhavikatti, S., Optimization Studies on Enzymatic Clarification of Mixed Fruit Juices. International Journal of Latest Trends in Engineering and Technology, 5(2), 2015, pp.161-165.

53. Umsza-Guez, M.A., Rinald, R., Lago-Vanzelal, E.S., Martin, N., Da Silva, R., Gomes, E., Thomeo, J. C., Effect of pectinolitic enzymes on the physical properties of caja-manga (Spondias cytherea Sonn.) pulp. Cienc. Tecnol. Aliment., Campinas, 31(2), 2011, pp. 517-526.

54. Abdullah, A. G. L., Sulaiman, N.M., Aroua, M. K., Noor, M.J.M.M., Response surface optimization of conditions for clarification of carambola fruit juice using a commercial enzyme. Journal of Food Engineering, 81, 2007, pp. 65-71.

55. Sin, H. N. Yusof, S., Sheikh Abdul Hamid, N., Abd. Rahman, A., Optimization of enzymatic clarification of sapodilla juice using response surface methodology. Journal of FoodEngineering, 73, 2006, pp. 313-319.

56. Jori, D. B, Pawar, A. V., Kudake, D. C., and Kotgirkar, P.
G.,Multienzymatic Clarification of Blended Pineapple and Mango Pulp Using Response Surface Methodology. International Journal of Advanced Biotechnology and Research, 6(1), 2015, pp 49-56.

\section{AUTHORS PROFILE}

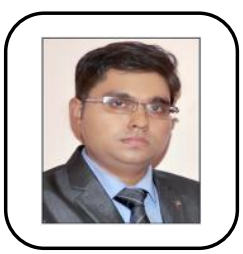

Ravi Kumar, M. Tech. in Chemical Technology with Specialization in Food Technology from HBTI, Kanpur and pursuing Ph. D. in the Department of Food Technology at School of Chemical technology, Harcourt Butler Technical University, Kanpur, Uttar Pradesh, India. His areas of interest are Fruit and Vegetable Processing, Value Added Food Products, Functional and Nutraceutical foods, Beverage Processing etc. He has one year of industrial and seven years of academic experience. He is also member of various academic societies such as AFST(I) [Association of Food Scientists \& Technologists (India)] ABEFT (Association of Biochemical Engineers and Food Technologists), HBTU etc.

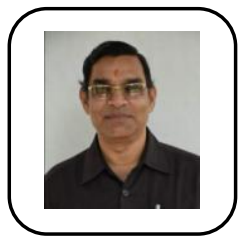

Dr. Alak Kumar Singh is presently working as Professor and Head in Department of Food Technology, School of Chemical technology, Harcourt Butler Technical University, Kanpur, Uttar Pradesh, India. He holds B. Tech in Chemical Technology (Food Technology) in 1993 and M. Tech in Chemical Technology, Food Technology in 1995 from HBTI, Kanpur UP, and accomplished Ph.D. in Chemical Technology from U. P. Technical University, Lucknow in 2013 and has been a passionate teacher. Prof. Singh possesses more than 24 years of experience in teaching, researches and academic administration. He is member of academic and research committees of various Universities. Prof. Singh has published 16 International / National research papers and Supervised 3 Ph.D. \& number of $\mathrm{M}$. Tech, thesis. He is reviewer in various National and international journals. His research contributions are in the area of Fruit \& Vegetables, Dairy Products, Waste Management and Food Biotechnology. He has completed two research project of worth Rs 60 Lakhs of U P Council of Science \& Technology and Ministry of Food Processing Industries, Government of India. He is life member of AFSTI and Oil Technologists Association of India. He is GATE Score and ranked first in M. Tech program at HBTI Kanpur. He had delivered many lectures / keynote address and chaired various technical sessions during nation and international conferences and training program. $\mathrm{He}$ also organized and contributed to several faculty development programs for teachers and training programs for students. 